Original article

Reprint

\title{
Evaluating biocompatibility of vaterite-mineralized polycaprolactone matrices in subcutaneous implantation tests on white rats
}

\author{
Aleksei N. Ivanov ${ }^{1}$, Mariya O. Kurtukova ${ }^{1}$, Maksim N. Kozadayev ${ }^{1}$, Dariya A. Tyapkina ${ }^{1}$, \\ Sergei V. Kustodov ${ }^{1}$, Mariya S. Savelieva ${ }^{2}$, Irina O. Bugaeva ${ }^{1}$, Bogdan V. Parakhonsky ${ }^{2}$, \\ Elena A. Galashina ${ }^{1}$, Ekaterina V. Gladkova ${ }^{1}$, Igor A. Norkin ${ }^{1}$ \\ ${ }^{1}$ Saratov State Medical University, Saratov, Russia \\ ${ }^{2}$ Saratov State University, Saratov, Russia
}

Received o2 August, 2018, Accepted 21 January, 2020

Original Text (c) Ivanov A.N., Kurtukova M.O., Kozadaev M.N., Tyapkina D.A., Kustodov S.V., Saveleva M.S., Bugaeva I.O., Parakhonsky B.V., Galashina E.A., Gladkova E.V., Norkin I.A., 2018, published in Saratov Journal of Medical Scientific Research $2018 ; 14$ (3): $451-456$.

(C) 2020, Ivanov A.N., Kurtukova M.O., Kozadaev M.N., Tyapkina D.A., Kustodov S.V., Saveleva M.S., Bugaeva I.O., Parakhonsky B.V., Galashina E.A., Gladkova E.V., Norkin I.A.

(C) 2020, Saratov Medical Journal

\begin{abstract}
:
Objective: to estimate biocompatibility of matrices manufactured from polycaprolactone (PCL) and mineralized by vaterite $(\mathrm{CaCO} 3)$ via studying local and systemic manifestations of inflammatory reaction in subcutaneous implantation tests on white rats.

Material and Methods. The experiment was conducted on 40 rats divided into four groups of equal sizes: control, comparison (rats with imitation of implantation), negative control (rats with implanted non-biocompatible matrices) and experimental group, comprised of animals with implanted $\mathrm{PCL} / \mathrm{CaCO}_{3}$-matrices. Local inflammatory manifestations were analyzed by morphological investigation of implantation area tissues. Systemic inflammatory manifestations were estimated via TNF- $\alpha$ and interleukin-1 $\beta$ (IL-1) concentrations in blood serum by ELISA.

Results. The changes in cellular population content demonstrated that, on day 21 after the implantation, the PCL/CaCO3matrice was evenly colonized by fibroblast cells and afterwards vascularized. Such matrices did not cause intense inflammatory reaction observed in negative control animals. It was accompanied by systemic manifestations, such as statistically significant increase in TNF- $\alpha$ and IL-1 concentrations.

Conclusion. Our data confirmed the biocompatibility of $\mathrm{PLC} / \mathrm{CaCO} 3$-scaffolds, thus experimentally substantiating the potential for their use in tissue engineering.
\end{abstract}

Keywords: regeneration, scaffolds, vaterite, biocompatibility, polycaprolactone.

Cite as Ivanov AN, Kurtukova MO, Kozadayev MN, Tyapkina DA, Kustodov SV, Savelieva MS, Bugaeva IO, Parakhonsky BV, Galashina EA, Gladkova EV, and IA Norkin. Evaluating biocompatibility of vaterite-mineralized polycaprolactone matrices in subcutaneous implantation tests on white rats. Saratov Medical Journal 2020; 1(1): e0102

Correspondence to Aleksei N. Ivanov. Tel.: +7(927)2799599. E-mail: lex558452@gmail.com

\section{Introduction}

Currently, one of the most important areas of tissue engineering is the development of scaffolds designed to stimulate regeneration processes. Scaffolds are threedimensional porous structures that, when implanted into a defect zone, function as an extracellular skeleton. On the periphery and in the depth of these structures, regeneration occurs due to the matrix colonized by cellular elements [1]. A wide range of materials of both natural and artificial origins is used to manufacture scaffolds [2]. To ensure the possibility of chemical modification and high multifunctionality, the preference in the development of scaffolds is given to artificial materials, one of which is polycaprolactone (PCL) [3]. This polymer is capable of biodegradation in vivo with formation of the products without toxic effect on surrounding tissues and the whole body [4]
To improve osteoinductive and osteoconductive properties of the matrices, scaffolds include inorganic substances stimulating such processes. One of these compounds is vaterite $\left(\mathrm{CaCO}_{3}\right)$ capable of activating proliferation of bone tissue cells and, upon transformation to calcite, participating in the target delivery of the substances and releasing pre-absorbed biologically active molecules in defect areas $[5,6]$.

One of the major properties required in scaffolds is their biocompatibility. Matrices should have an ability to vascularize and to be colonized by cellular elements. Also, they should not lead to the negative changes in the body. Subcutaneous implantation tests are among important and mandatory items in scaffold biocompatibility assessment [7].

The objective of our study was to assess the biocompatibility of matrices from vaterite-mineralized polycaprolactone via identifying local and systemic 
manifestations of inflammatory reaction in subcutaneous implantation tests conducted on white laboratory rats.

\section{Material and methods}

The experiment was performed on 40 white non-pedigree male rats weighing 200-250 g, divided into four equal groups of ten: the control group consisting of intact rats; comparison group, including sham-operated animals, which underwent a full-scale surgery without implantation of the matrices; negative control group (animals implanted with PCL-based non-biocompatible matrices with absorbed foreign protein), and experimental group with subcutaneously implanted $\mathrm{PCL} / \mathrm{CaCO} 3$ scaffolds.

Experimental work was conducted along the guidelines of several official documents: European Convention for Protection of Vertebrate Animal Used for Experimental and Other Scientific Purposes (adopted by the Council of Europe in 1986), Declaration of Helsinki by the World Medical Association (1989), International Guiding Principles for Biomedical Research Involving Animals (1985), and the Order No. 267 of the Russian Federation Ministry of Health from June 19, 2003 "On approval of laboratory practice rules". The study was carried out in accordance with the recommendations of the Ethics Committee of V.I. Razumovsky Saratov State Medical University (protocol No. 6 of February 6, 2018). A combination of telazol (Zoetis Inc., USA) at a dose of $0.1 \mathrm{ml} / \mathrm{kg}$ and xylazine (Interchemie, Netherlands) at a dose of $1 \mathrm{mg} / \mathrm{kg}$ was administered intramuscularly to anesthetize animals, while performing all manipulations on them.

Matrices based on PCL, made by electroforming at the Institute of Nanostructures and Biosystems, Saratov State University, were used for implantation. Animals of the negative control group were implanted with non-mineralized matrices with adsorbed foreign protein (native ovalbumin) on the surface. Scaffolds mineralized with vaterite sensu the method, described by M.S. Savelyeva, A.N. Ivanov, M.O. Kurtukova et al. [5], were used for implantation into animals of the experimental group.

To implant matrices, an incision on depilated and antiseptic-treated interscapular region, was performed. Then in the wound under the skin, a pocket sized $15 \times 15 \mathrm{~mm}$ was formed, using the ramus of the forceps, into which the scaffold shaped as a $10 \mathrm{~mm}$ disk was placed. After placing the scaffolds in the subcutaneous pocket, the wound was sutured tightly using a non-absorbable monofilament yarn Resorpen 3-O USP (RESORBA MedicalGmbH, Germany), and treated with $70 \%$ ethyl alcohol.

On the 21st day after the true or false implantation of the matrices, blood samples were taken by the puncture of the venous heart under anesthesia. Five-milliliter blood samples were collected in Vacuette tubes with clot activator and barrier gel. Blood serum was obtained by centrifuging at $3000 \mathrm{rpm}$. Aliquots of serum were frozen and stored at 200C. The concentrations of TNF (tumor necrosis factor) and IL-1 (interleukin-1) were determined in the serum of experimental animals by ELISA (enzyme-linked immunosorbent assay) using the "IL-1 $\beta$ rat" and "TNF- $\alpha$ rat" reagent kits by eBioscience (BenderMedSystems, Austria) and a microplate spectrophotometer Anthos-2020 (Biochrom, the United Kingdom).

After the blood sampling, the animals were removed from the experiment by an overdose of narcosis drugs. For histological examination, a scaffold with surrounding tissues (C) 2020, Saratov State Medical University, Saratov, Russia was removed as a single unit. The material for the study was fixed in a $10 \%$ neutral formalin solution (OOO "Biovitrum", Russia), dehydrated in ethyl alcohols, and then poured into paraffin. Slices 5-7 $\mu \mathrm{m}$ thick were stained with Mayer's hematoxylin (OOO "Biovitrum", Russia) and eosin (OOO "Biovitrum", Russia). Bio-Monht (BioOptica, Italy) was used to cover the slices.

The specimens were studied with a microscope AxioImager Z2 (CarlZeiss, Germany) and a microvisor of transmitted light, $\mu$ Vizo-103 series (OOO "Lomo Photonica", Russia). Histological specimens were tested for local signs of inflammatory reaction: oedema, hyperemia, or infiltration of scaffold and surrounding tissues with immunocompetent cells. A morphometric count of the cell number in each cell population was performed at $63 \mathrm{x}$ magnification: fibroblasts, fibrocytes, neutrophils, eosinophils, lymphocytes, plasma cells and macrophages in five fields of view of the scaffold and its perifocal area.

Statistical data processing was performed using the software package Statistica 10.0. We tested the hypotheses regarding the type of variation series distribution (Shapiro Wilk criterion). Most of our data did not comply with normal distribution; hence, to compare the values, we used the Mann-Whitney U-test, on the basis of which Z-criterion values and the confidence values of the difference (p) were calculated. Differences were considered significant at $\mathrm{p}$ $<0.05$.

Table 1. Cell populations of perifocal area of $\mathrm{PCL} / \mathrm{CaCO}_{3}^{-}$ scaffolds and matrices with absorbed foreign protein in comparison with connective tissue of the imitated implantation zone of sham-operated animals

\begin{tabular}{|c|c|c|c|}
\hline $\begin{array}{l}\text { Mean number of } \\
\text { cells in five fields of } \\
\text { view }\end{array}$ & $\begin{array}{l}\text { Comparison } \\
\text { group }(\mathrm{n}=10)\end{array}$ & $\begin{array}{l}\text { Negative } \\
\text { control group } \\
(\mathrm{n}=10)\end{array}$ & $\begin{array}{l}\text { Experimental } \\
\text { group }(\mathrm{n}=10)\end{array}$ \\
\hline Fibroblasts & $15(10 ; 18)$ & 34) $\begin{array}{l}30 \quad(15 ; \\
\mathrm{p}_{1}<0,05\end{array}$ & $\begin{array}{l}13 \quad(10 ; \\
15) \\
\mathrm{p}_{1}>0,05 \\
\mathrm{p}_{2}<0,05\end{array}$ \\
\hline Fibrocytes & $9(5 ; 12)$ & $\begin{array}{l}9(6 ; 13) \\
\mathrm{p}_{1}>0,05\end{array}$ & $\begin{array}{l}11(7 ; 16) \\
p_{1}>0,05 \\
p_{2}>0,05\end{array}$ \\
\hline $\begin{array}{l}\text { Polymorphonuclear } \\
\text { leukocytes }\end{array}$ & $0(0 ; 0)$ & $\begin{array}{l}3(2 ; 5) \\
\mathrm{p}_{1}<0,001\end{array}$ & $\begin{array}{l}0(0 ; 0) \\
\mathrm{p}_{1}>0,05 \\
\mathrm{p}_{2}<0,001\end{array}$ \\
\hline Lymphocytes & $2(0 ; 3)$ & $\begin{array}{l}7(3 ; 11) \\
\mathrm{p}_{1}<0,05\end{array}$ & $\begin{array}{l}0(0 ; 1) \\
\mathrm{p}_{1}>0,05 \\
\mathrm{p}_{2}<0,001\end{array}$ \\
\hline Macrophages & $2(2 ; 5)$ & $\begin{array}{l}6(4 ; 7) \\
\mathrm{p}_{1}<0,05\end{array}$ & $\begin{array}{l}1(1 ; 2) \\
\mathrm{p}_{1}>0,05 \\
\mathrm{p}_{2}<0,001\end{array}$ \\
\hline
\end{tabular}

Median, upper and lower quartiles are presented in each case; $\mathrm{p}_{1}, \mathrm{p}_{2}-$ as compared with sham-operated animals and with animals of negative control group correspondingly 


\section{Results}

During the morphological study of imitated matrix implantation areas in the comparison group on the 21st day of the experiment, local signs of inflammation, including oedema, vascular congestion and leukocyte infiltration, were not detected. Fibroblastic cells prevailed in the connective tissue of the implantation area.

Thus, the proportion of fibroblasts was $54 \%$ of the total cell number. Fibrocytes were detected at 32\%. Single leukocytes, mainly lymphocytes and macrophages (Table 1), were also found. Concentrations of pro-inflammatory cytokines in the group of sham-operated animals on the 21st day of the experiment did not have statistically significant differences from the levels of TNF and IL-1 of intact rats (Table 3).

On the 21st day after the implantation of a matrix with foreign protein in negative control group, a connective tissue barrier infiltrated with leukocytes, tissue oedema of the perifocal region, as well as a vascular congestion of arterial and venous beds in this zone were detected around the scaffold. Morphometric analysis showed that, in the perifocal area of a non-biocompatible scaffold, the number of fibroblasts was two times higher than that in the specimens of sham-operated animals. At the same time, the numbers of fibrocytes among the specimens of these groups did not have statistically significant differences (Table 1). Thirteen per cent of lymphocytes and $11 \%$ of macrophages dominated the total blood cell counts in the leukocyte infiltration of the perifocal area of scaffolds in the negative control group. In addition, polymorphonuclear leukocytes, predominantly neutrophils, in significantly higher numbers than in shamoperated animals, were found in the cell populations of the perifocal area of the scaffold in animals of this group (Table 1).

Table 2. Cell populations of $\mathrm{PCL} / \mathrm{CaCO}_{3}$-scaffolds and matrices with absorbed foreign protein in comparison with connective tissue of the imitated implantation zone of sham-operated animals

\begin{tabular}{|c|c|c|c|}
\hline $\begin{array}{l}\text { Mean number } \\
\text { of cells in five } \\
\text { fields of view }\end{array}$ & $\begin{array}{l}\text { Comparison } \\
\text { group }(\mathrm{n}=10)\end{array}$ & $\begin{array}{l}\text { Negative } \\
\text { control group } \\
(\mathrm{n}=10)\end{array}$ & $\begin{array}{l}\text { Experimental } \\
\text { group }(\mathrm{n}=10)\end{array}$ \\
\hline Fibroblasts & $15(10 ; 18)$ & $\begin{array}{l}5(1 ; 12) \\
\mathrm{p}_{1}<0,001\end{array}$ & $\begin{array}{l}38(21 ; \\
47) \\
\mathrm{p}_{1}<0,001 \\
\mathrm{p}_{2}<0,001 \\
\end{array}$ \\
\hline Fibrocytes & $9(5 ; 12)$ & $\begin{array}{c}2(0 ; 6) \\
\mathrm{p}_{1}<0,001\end{array}$ & $\begin{array}{l}22(13 ; \\
32) \\
\mathrm{p}_{1}<0,001 \\
\mathrm{p}_{2}<0,001\end{array}$ \\
\hline $\begin{array}{l}\text { Polymorpho- } \\
\text { nuclear } \\
\text { leukocytes }\end{array}$ & $0(0 ; 0)$ & $\begin{array}{l}13(5 ; 16) \\
\mathrm{p}_{1}<0,001\end{array}$ & $\begin{array}{c}0(0 ; 1) \\
\mathrm{p}_{1}>0,05 \\
\mathrm{p}_{2}<0,001\end{array}$ \\
\hline Lymphocytes & $2(0 ; 3)$ & $\begin{array}{l}3(2 ; 3) \\
\mathrm{p}_{1}>0,05\end{array}$ & $\begin{array}{l}2(0 ; 4) \\
\mathrm{p}_{1}>0,05 \\
\mathrm{p}_{2}>0,05\end{array}$ \\
\hline Macrophages & $2(2 ; 5)$ & $\begin{array}{l}4(2 ; 6) \\
\mathrm{p}_{1}>0,05\end{array}$ & $\begin{array}{l}2(0 ; 4) \\
\mathrm{p}_{1}>0,05 \\
\mathrm{p}_{2}<0,05\end{array}$ \\
\hline
\end{tabular}

Median, upper and lower quartiles are presented in each case; $\mathrm{p}_{1}, \mathrm{p}_{2}-$ as compared with sham-operated animals and with animals of negative control group correspondingly
Table 3. Concentrations of pro-inflammatory cytokines in blood plasma of experimental animals

\begin{tabular}{|c|l|l|}
\hline Groups & TNF, $\mathrm{pg} / \mathrm{ml}$ & $\mathrm{IL}-1, \mathrm{pg} / \mathrm{ml}$ \\
\hline Control $(\mathrm{n}=8)$ & $9,5(5,6 ; 11,6)$ & $16,1(13,9 ; 16,6)$ \\
\hline $\begin{array}{c}\text { Comparison group } \\
(\mathrm{n}=6)\end{array}$ & $7,2(6,8 ; 8,4)$ & $14,9(14,2 ; 15,6)$ \\
\hline \multirow{2}{*}{ Negative control } & $15,7(12,4 ; 16,5)$ & $27,5(23,6 ; 31,5)$ \\
$(\mathrm{n}=9)$ & $\mathrm{p}_{1}<0,05$ & $\mathrm{p}_{1}<0,001$ \\
& $\mathrm{p}_{2}<0,05$ & $\mathrm{p}_{2}<0,05$ \\
\hline & $7,6(3,5 ; 8,4)$ & $16,6(12,2 ; 18,1)$ \\
Experimental group & $\mathrm{p}_{1}>0,05$ & $\mathrm{p}_{1}>0,05$ \\
$(\mathrm{n}=7)$ & $\mathrm{p}_{2}>0,05$ & $\mathrm{p}_{2}>0,05$ \\
& $\mathrm{p} 3<0,05$ & $\mathrm{p}_{3}<0,05$ \\
\hline
\end{tabular}

TNF - tumor necrosis factor $\alpha$; IL -1 - interleukin-1 $\beta$; median, upper and lower quartiles are presented in each case. $p_{1-}$ as compared with animals of control group; $\mathrm{p}_{2}$ - as compared with sham-operated animals; $\mathrm{p}_{3}-$ as compared with animals of negative control group

For animals of the negative control group, a weak colonization of the matrix with fibroblastic elements was observed, while no signs of vascularization were detected. The numbers of fibroblasts and fibrocytes in nonbiocompatible matrix were 3 and 4.5 times, respectively, lower than in the connective tissue of the imitated implantation zone of sham-operated rats (Table 2). In PCLscaffold with adsorbed foreign protein, we observed the prevalence of polymorphic leukocytes, which accounted for about $48 \%$ of the total cell count (see Table 2). Lymphocytes and macrophages averaged 11 and $15 \%$, respectively, of the total blood cell count (see Table 2).

For negative control animals, on the 21st day of the experiment, a statistically significant increase in TNF concentration was detected compared with control and shamoperated rats: by a factor of 1.7 or 2, respectively (see Table 3). An increase in the concentrations of IL-1 was also revealed: by 1.7 and 1.9 times compared with the control group and sham-operated animals, respectively (Table 3).

On the 21st day of the experiment, moderate blood filling of the microvasculature was indicated in the perifocal zone of the $\mathrm{PCL} / \mathrm{CaCO}_{3}$ scaffold for the experimental group animals. However, oedemas, leukocyte infiltration, signs of the formation of a boundary barrier around the $\mathrm{PCL} / \mathrm{CaCO}_{3}$ scaffold for the animals of this group were not detected. The predominant cell type in the perifocal area was fibroblasts. Thus, after morphometry, it was established that the number of fibroblasts and fibrocytes reached $52 \%$ and $44 \%$ of the total cell counts (Table 1). Simultaneously, the number of fibroblasts in the perifocal area of the animals in this group was 2.3 times lower than around non-biocompatible matrices in the negative control group (Table 1). The numbers of leukocytes, macrophages and neutrophils in the perifocal area of the PCL/CaCO3 scaffold did not differ significantly from the cellular composition of the tissues in the imitated implantation area of sham-operated animals but was significantly lower than in the perifocal area of nonbiocompatible matrices in the negative control group (Table $1)$.

On the 21st day after implantation, $\mathrm{PCL} / \mathrm{CaCO}_{3}$ scaffold was colonized by fibroblastic elements and then vascularized. The number of fibroblasts and fibrocytes in the PCL/CaCO 3 scaffold was 2.5 times higher than in non-biocompatible matrices (Table 2). These cell populations amounted to $34 \%$ and $60 \%$ of the total cell count, respectively. Single 
leukocytes were found in the structure of $\mathrm{PCL} / \mathrm{CaCO}_{3}$ scaffold but their numbers did not differ significantly from the cellular composition of the connective tissue in the imitated implantation area of sham-operated animals, (Table 2). The number of leukocytes in $\mathrm{PCL} / \mathrm{CaCO} 3$ scaffolds was 1,5 -2 times lower than in non-biocompatible scaffolds for rats in the negative control group (Table 2).

The concentrations of TNF and IL-1 in the blood of animals from the experimental group did not differ from those of rats of the comparison and control groups. The concentrations of TNF and IL-1 in the serum of rats on the 21st day after the implantation of $\mathrm{PCL} / \mathrm{CaCO}_{3}$ scaffolds were 2.1 and 1.7 times lower, respectively, than in the animals of the negative control group (Table 3).

\section{Discussion}

The results of our study suggested that on the 21st day of the experiment, sham-operated animals had neither evidence of inflammation (in the area of imitated matrix implantation) nor systemic manifestations of inflammatory response. Therefore, by the 21st day of the experiment, the inflammatory changes due to post-surgery tissue injury were completely disappearing.

For negative control animals in contrast to comparison group rats, distinct inflammatory changes were noted in the implantation zone of the matrix with a foreign protein. Previously published studies demonstrated that, after subcutaneous implantation of matrices with adsorbed foreign protein, local inflammatory vascular changes were persistently recorded from the 7 th through the 21st day of the experiment [7-9]. Other published studies noted that nonbiocompatible scaffolds were not colonized by connective tissue elements and did not vascularize [10]. Our data implied that negative control animals had a significant increase in the concentrations of pro-inflammatory cytokines TNF and IL-1 in their blood, which represented systemic manifestations of inflammatory response. Elevated levels of TNF and IL-1 in rats with subcutaneous implantation of nonbiocompatible scaffolds explained the mechanism of vascular changes. Consequently, after the subcutaneous implantation of non-biocompatible scaffolds, white rats experienced a significant inflammatory reaction, characterized by typical local and systemic manifestations on the 21st day.

Our results indicated that subcutaneous implantation of $\mathrm{PCL} / \mathrm{CaCO}_{3}$ scaffolds in white rats of experimental group, in contrast to the negative control group, did not result in local signs of inflammation in the perifocal area. The composition of cell populations of the perifocal zone of $\mathrm{PCL} / \mathrm{CaCO} 3$ scaffolds did not differ significantly from the connective tissue of the implantation imitation zone in comparison group rats. The concentration of cytokines in blood on the 21st day after PCL/CaCO3 scaffold implantation was similar to cytokine concentration in intact rats, which confirmed an absence of inflammation manifestations. However, on the 21st day of the experiment, an active colonization of $\mathrm{PCL} / \mathrm{CaCO} 3$ scaffolds with connective tissue elements and their vascularization were observed, which, along with the absence of inflammatory changes in the perifocal zone, suggested biocompatibility of this type of matrices.

At present, the most promising concept of developing composite scaffolds for stimulating bone tissue regeneration involves a combination of synthetic polymers, such as PCL, and mineral compounds in the structure of matrices [11-14]. The results of numerous studies conducted abroad implied a high degree of biocompatibility of PCL matrices containing calcium phosphate compounds as the basis of the mineral component for the bone tissue [11, 12, and 14]. These studies demonstrated the biocompatibility of PCL scaffolds mineralized with hydroxyapatite [14], calcium betatriphosphate $[11,12]$, and two-phase calcium phosphate, which is essentially a mixture of the first two compounds [13]. Our earlier research was consistent with results of international authors and confirmed biocompatibility of both non-mineralized PCL matrices and PCL matrices mineralized by hydroxyapatite [10].

Vaterite is the least stable form of calcium carbonate [15]. In vitro experiments demonstrated that vaterite nanoparticles in hydrogel matrices do not possess cytotoxicity and, under the influence of intercellular fluid or phosphate buffer, are transformed into hydroxyapatite [15]. However, the PubMed database up to date has only two publications $[5,16]$ devoted to PCL matrices mineralized with vaterite. It was shown that PCL / $\mathrm{CaCO}_{3}$ scaffolds had mechanical parameters matching human cancellous bone tissue, while osteoblasts had the ability for conglutination on these matrices in vitro [16]. Our data on the composition of cell populations of the matrices and on the absence of systemic manifestations in the course of their implantation confirmed previously published studies $[5,9]$ and permitted us to conclude that $\mathrm{PCL} / \mathrm{CaCO}_{3}$ scaffolds were not inferior to polycaprolactone scaffolds judging from their biocompatibility properties.

\section{Conclusion}

Lack of scaffold biocompatibility showed itself as inflammation in the area of its implantation, which was accompanied by a characteristic change in the composition of cellular populations of connective tissue in the perifocal area. Consequently, scaffold cell populations were represented mainly by leukocytes dominated by neutrophils. Local tissue reactions were associated with systemic manifestations of the inflammatory response, characterized by an increase in the concentration of pro-inflammatory cytokines: TNF and IL-1. When PCL/CaCO3 scaffolds were implanted, neither local nor systemic signs of inflammation in the surrounding scaffold tissues were observed. The composition of cell populations of scaffolds was characterized by prevalence of fibroblastic cells. The combination of biochemical and morphometric data indicated a high degree of $\mathrm{PCL} / \mathrm{CaCO} 3$ scaffolds biocompatibility, thus experimentally substantiating the possibility of their use for tissue engineering.

\section{Conflict of interest}

The work was performed as part of the Federal assignment to V.I. Razumovsky Saratov State Medical University by the Russian Ministry of Healthcare "Development of technology for assessing the regenerative potential of matrices for replacing bone tissue defects based on their vascularization parameters". Registration number: AAAA-A18-118020290178-3 


\section{References}

1. Do AV, Khorsand B, Geary SM, et al. 3D Printing of Scaffolds for Tissue Regeneration Applications. Adv Healthcare Mater 2015; 4: 1742-62.

2. Ivanov AN, Norkin IA, Puchinyan DM. The possibilities and perspectives of using scaffold technology for bone regeneration. Tsitologiya 2014; 56(8): 543-8.

https://www.semanticscholar.org/paper/\%5BThe-possibilitiesand-perspectives-of-using-for-Ivanov Norkin/f41b6d46cec870dae2bo757588dfdc56b83534b3

3. Novochadov VV. The Problem of cell settling and remodeling of tissue-engineered matrices for regeneration of the articular cartilage. Bulletin of Volgograd State University 2013; 1(5): 1928.

4. Mkhabela V, Ray SS. Biodegradation and bioresorption of poly (e-caprolactone) nanocomposite scaffolds. International Journal of Biological Macromolecules 2015; 79: 186-92.

http://dx.doi.org/10.1016/j.ijbiomac.2015.04.056

5. Saveleva MS, Ivanov AN, Kurtukova MO, et al. Hybrid PCL/CaCO3 scaffolds with capabilities of carrying biologically active molecules: synthesis, loading and in vivo applications. Materials Science \& Engineering C-Materials for Biological Applications 2018; 85: 57-67.

6. El-Fiqi A, Kim JH, Kim HW. Osteoinductive fibrous scaffolds of biopolymer / mesoporous bioactive glass nanocarriers with excellent bioactivity and long-term delivery of osteogenic drug. ACS Appl Mater Interfaces 2015; 7 (2): 1140-52.

7. Ivanov AN, Kozadaev MN, Puchinyan DM, et al. Microcirculatory changes during stimulation of tissue regeneration by scaffold based on the polycaprolactone. Regional Blood Circulation and Microcirculation 2015; 14(54): 70-5.

https://doi.org/10.24884/1682-6655-2015-14-2-70-75

8. Ivanov $\mathrm{AN}$, Kozadaev MN, Belova SV, et al. Comparative analysis of perfusion and dynamics of acute-phase markers of inflammatory response after polycaprolactone hydroxyapatite matrix implantation. Modern Problems of Science and Education 2016; 4: 15 .

https://science-education.ru/en/article/view?id=248211

9. Norkin IA, Ivanov AN, Kurtukova MO, et al. Peculiarities of microcirculatory reactions after implantation subcutaneous polycaprolactone matrices, mineralized vaterite. Saratov Journal of Medical Scientific Research 2018; 14(1): 35-41.

https://cyberleninka.ru/article/n/osobennostimikrotsirkulyatornyh-reaktsiy-pri-subkutannoy-implantatsiipolikaprolaktonovyh-matrits-mineralizovannyh-vateritom

10. Ivanov AN, Kozadaev MN, Bogomolova NV, et al. The study of the biocompatibility of the matrix based on polycaprolactone and hydroxyapatite in vivo. Tsitologiya 2015; 57(4): 286-93.

11. Bang LT, Ramesh S, Purbolaksono J, et al. Development of a bone substitute material based on alpha-tricalcium phosphate scaffold coated with carbonate apatite / poly-epsiloncaprolactone. Biomed Mater 2015; 10(4): 045011. http://dx.doi.org/10.1088/1748-6041/10/4/045011

12. Nyberg E, Rindone A, Dorafshar A, et al. Comparison of $3 \mathrm{D}-$ Printed Poly- $\varepsilon$-Caprolactone Scaffolds Functionalized with Tricalcium Phosphate, Hydroxyapatite, Bio-Oss, or Decellularized Bone Matrix. Tissue Eng Part A 2017; 23(11-12): 503-14. https://doi.org/10.1007/7651 2017 37

13. Thuaksuban $\mathrm{N}$, Pannak $\mathrm{R}$, Boonyaphiphat $\mathrm{P}$, et al. In vivo biocompatibility and degradation of novel PolycaprolactoneBiphasic Calcium phosphate scaffolds used as a bone substitute. Biomed Mater Eng 2018; 29(2): 253-67. http://dx.doi.org/10.3233/BME-171727

14. Zomorodian A, Garcia MP, Moura E, et al. Biofunctional composite coating architectures based on polycaprolactone and nanohydroxyapatite for controlled corrosion activity and enhanced biocompatibility of magnesium AZ31 alloy. Mater Sci Eng C Mater Biol App. 2015; 48: 434-43.
15. Schroder R, Pohlit H, Schuler T, et al. Transformation of vaterite nanoparticles to hydroxycarbonate apatite in a hydrogel scaffold: relevance to bone formation. Journal of Materials Chemistry $B$ 2015; 3: 7079-89.

https://pubs.rsc.org/en/Content/ArticleLanding/2015/TB/C5TB 01032B\#!divAbstract

16. Olah L, Borbas L. Properties of calcium carbonate-containing composite scaffolds. Acta Bioeng Biomech 2008; 10(1): 61-6. https://pubmed.ncbi.nlm.nih.gov/18634355/

\section{Authors:}

Aleksei N. Ivanov - DSc, Head of Central Science and Research Laboratory, Lead Research Scientist at Division of Basic, Clinical and Experimental Studies, Chair of Laboratory Diagnostic Division, Research Institute of Traumatology, Orthopedics and Neurosurgery, Saratov State Medical University, Saratov, Russia;

Mariya O. Kurtukova - PhD, Assistant Professor, Department of Histology, Saratov State Medical University, Saratov, Russia;

Maksim N. Kozadayev - PhD, Junior Research Scientist, Division of Basic, Clinical and Experimental Studies, Research Institute of Traumatology, Orthopedics and Neurosurgery, Saratov State Medical University, Saratov, Russia;

Dariya A. Tyapkina - undergraduate student at School of General Medicine, Saratov State Medical University, Saratov, Russia;

Sergei V. Kustodov - undergraduate student at School of General Medicine, Saratov State Medical University, Saratov, Russia;

Mariya S. Savelieva - Engineer, Institute of Nanostructures and Biosystems, Saratov State University, Saratov, Russia;

Irina O. Bugaeva - DSc, Professor, Chair of Histology Department, Vice-Chancellor for Academic Affairs, Saratov State Medical University, Saratov, Russia;

Bogdan V. Parakhonsky - PhD, Senior Research Scientist, Institute of Nanostructures and Biosystems, Saratov State Medical University, Saratov, Russia;

Elena A. Galashina - PhD, Junior Research Scientist, Division of Basic, Clinical and Experimental Studies, Research Institute of Traumatology, Orthopedics and Neurosurgery, Saratov State Medical University, Saratov, Russia;

Ekaterina V. Gladkova - PhD, Head of the Division of Basic, Clinical and Experimental Studies, Research Institute of Traumatology, Orthopedics and Neurosurgery, Saratov State Medical University, Saratov, Russia;

Igor A. Norkin - DSc, Professor, Chair of Traumatology and Orthopedics Department, Director of Research Institute of Traumatology, Orthopedics and Neurosurgery, Saratov State Medical University, Saratov, Russia. 